\title{
Essay
}

\section{Om anoreksi og jagten på nydelse}

\section{Rasmus Rask Jepsen}

Aarhus Universitet

rasklol@gmail.com

Jepsen, Rasmus Rask (2018). 'Om anoreksi og jagten på nydelse' i Tidsskrift for Forskning i Sygdom og Samfund, nr. 29, 173-191.

At være glad for sig selv, elske sig selv, nyde sig selv synes at være det højeste mål $i$ livet for mange i dag. Men selvom vi forsøger at indrette vores liv derefter, er det alligevel, som om vi ikke rigtig lykkes med at indfri dette mål. Vi lever med Slavoj Žižeks ord i dag i et nydelsessamfund, hvor vi påbydes altid at nyde lidt mere og lidt bedre. Det er dette påbud, som tyranniserer samtidens individer og efterlader dem med en følelse af skyld og utilstrækkelighed.

I artiklen analyseres sygdommen anoreksi som et symptom på samtidens overopmærksom på nydelse. Anorektikeren er et eksempel på en person, der er så optaget af at nyde sig selv og sin krop, at det slàr over i sin modsætning og bliver en smertefuld og ubehagelig lidelse, fordi hun altid føler sig skyldig over ikke at nyde godt nok.

Via udvalgte og illustrative citater fra pro-anorektiske internetfora og med udgangspunkt $i$ den lacanianske psykoanalyse og dennes begreb om (mer)nydelse, giver artiklen en forklaring på, hvad det er, den anorektiske sygdom tilbyder sine subjekter, og hvorfor disse subjekter insisterer på at holde fast $i$ sin sygdom, selvom de udmærket er klar over, hvor sundhedsskadelig og farlig den er. 
To be happy with oneself, to love oneself, to enjoy oneself seem to be the highest goal in life for many people today. However, even though we try our best to be and do just this, it is as if we never really succeed in achieving this goal. In the words of Slavoj Žižek we live in a society of enjoyment characterized by an injunction to enjoy (more and better). This injunction tyrannizes individuals of today and leaves them with a feeling of guilt and insufficiency.

In this article, the eating disorder of anorexia is analyzed as a symptom of the excessive attention towards enjoyment that exists today. The anorectic person constitutes a dialectic example of someone who is so obsessed with being happy with oneself and one's body that s/he ends up with the exact opposite: a painful and unpleasant suffering. The anorectic is in a constant feeling of doubt and guilt for not complying sufficiently with the injunction to enjoy.

This article combines the use of selectively chosen and illustrative quotes from proanorectic internet fora with the theoretical insights of lacanian psychoanalysis. Especially the lacanian notion of surplus enjoyment proves useful for understanding why anorexia is sometimes seen positively by those who experience it and why they do not wish to recover from it even if they know very well how unhealthy and dangerous it is.

\section{Introduktion}

Til kvinder, som har et problematisk forhold til deres krop, hører man ofte følgende råd: Du skal lære at være glad for dig selv, at elske dig selv og din krop. Eksempelvis har vi af DR for nylig fået programrækken "Petra elsker sig selv", i hvilken "vi følger Petras personlige rejse for at få svar på spørgsmålet: Hvordan lærer man at elske sin krop?"1. Stærke kvinder, som angiveligt lykkes med netop at elske sig selv, har vi også hørt fra i 2017. Ifølge Tone Frank Dandanell (2017) er det netop, hvad den såkaldte fjerdebølgefeminisme har handlet om: Kampen for at kunne vise sig frem ( $f x$ at tage nedringede kjoler på, at posere i undertøj eller at twerke) i offentligheden uden at skamme sig. Der er tilsyneladende tale om en form for frihed ("Jeg er kvinde, og jeg kan gøre som jeg vil") og en insisteren på retten til at elske sig selv. Problemet, som Dandanell rigtigt påpeger, er, at der snarere end frihed til selvkærlighed er tale om et påbud: Du skal elske dig selv.

Her har vi blot en af de måder, hvorpå man kan formulere det imperativ, som ifølge den slovenske filosof Slavoj Žižek kendetegner det postmoderne samfund, 
nemlig imperativet om at nyde. Den herskende ideologi er i dag ikke længere den patriarkalske, som forbyder os at nyde, men snarere den hedonistiske, som befaler os at nyde (Žižek 2011: 50). Hvor man tidligere følte sig skyldig over at nyde, føler vi os i dag skyldige over ikke at nyde. Vi har med andre ord bevæget os fra et forbudssamfund til et nydelsessamfund ${ }^{2}$.

Hvad angår begrebet om nydelse, som Žižek henter fra den franske psykoanalytiker Jacques Lacan, er det nødvendigt indledningsvis at gøre et par bemærkninger. For det første er nydelse et dialektisk begreb, hvilket kort sagt vil sige, at det indeholder sin egen modsætning. At spise et stykke chokoladekage er et oplagt eksempel på noget nydelsesfuldt. Men tænk også på hvordan det at undlade at spise chokoladekage og eventuelt løbe en tur i stedet kan give anledning til stor selvtilfredsstillelse. Ved at give afkald på nydelse får man paradoksalt nok del i en form for (mer-)nydelse (Dolar 1998: xviii). For det andet er nydelse i en lacaniansk optik derfor også altid at forstå som mer-nydelse ${ }^{3}$. Det betyder, at den ikke eksisterer som en velafgrænset størrelse, der kan måles og vejes. Den eksisterer kun som et overskud:

"Det er ikke et overskud, der blot knytter sig til en eller anden 'normal', fundamental nydelse, idet nydelsen som sådan kun viser sig i form af dette overskud, fordi det konstitutivt er et 'overmål'. Hois man trækker overskuddet fra, mister man nydelsen i sig selv" (Žižek 2010: 95).

Mer-nydelse er aldrig bare tilgængeligt, men kræver tilstedeværelsen af en form for forstyrrelse: en udskydelse, en barriere eller et forbud. Vi kan bare prøve at forestille os et samfund, hvor alt er tilladt og direkte tilgængeligt. Hvordan skulle man kunne komme i gang med at nyde? Har man fuld adgang til alt, er der ingen friktion, ingen spænding, ingen mer-nydelse.

I dag er nydelse imidlertid ikke forbudt (og heller ikke bare tilladt), men påbudt ifølge Žižek. Problemet i dag er måske derfor ikke fraværet af frihed: Individer, som lever i et moderne, vestligt samfund, har muligheden for at nyde og realisere sig selv på et utal af måder. Problemet i dag er, at muligheden for at nyde sig selv er blevet til en pligt, hvilket sætter det postmoderne individ i en umulig position. Nydelse har det nemlig med at være noget, der venter lige rundt om hjørnet: "Jeg skal bare lige X, førend alt er godt" fortæller vi os selv og hinanden. X kan være så forskellige ting som at "bestille en Gin \& Tonic ved poolen", "færdiggøre den her arbejdsopgave" eller "tabe mig 2kg mere". Sandheden er imidlertid, at nydelsen ofte kun viser sig på præcis denne måde, dvs. som mer-nydelse. Uanset hvor 
meget man prøver at nyde sig selv og sin tilværelse, kan man altid nyde lidt mere og lidt bedre, og imperativet om at nyde er derfor det, som tyranniserer samtidens individer.

Et paradigmatisk eksempel på, hvordan det kan komme til udtryk, er i udviklingen af spiseforstyrrelsen, anoreksi. I denne artikel analyserer jeg anoreksi som et symptom på samtidens overopmærksom på nydelse. Betragtes anorektikerens adfærd "udefra" fremstår den enormt patologisk og uforståelig: "Hvorfor vil hun ikke spise? Kan hun ikke se, at hun er alt for tynd og risikerer at dø, hvis ikke hun spiser?" spørger vi måske os selv og hinanden. Det er imidlertid min påstand, at vi bliver bedre i stand til forstå patologiens struktur, hvis vi sætter fokus på anorektikerens subjektive erfaringer og analyserer disse med udgangspunkt i det psykoanalytiske begreb om mer-nydelse. For mange virker det måske både overraskende og provokerende at påstå, at anoreksi har noget som helst at gøre med nydelse. Anoreksi er kendetegnet ved afmagring, tvangstanker og stort ubehag - kort sagt fraværet af nydelse. Sådan ser det i hvert fald ud, når man betragter det "udefra". Spørger man imidlertid anorektikere selv, kan man få svar á la: "My behaviours are the way I can achieve happiness, so they are very important for me" (Williams og Reid 2010: 559).

\section{En social patologi}

Anorexia nervosa, der betyder nervøs spisevægring, er en sygdom, som er mest udbredt blandt kvinder mellem 14-24 år med en forekomst på mellem 0,4 og 1 \%. Anoreksi "viser sig først og fremmest ved vægttab, en ekstrem frygt for at tage på trods undervægt samt en intens optagethed af kost, vægt og udseende. Den syge er stærkt undervægtig, men tilstræber alligevel yderligere vægttab" (Sundhedsstyrelsen 2000).

Betegnelsen anorexia nervosa bruges første gang i 1870'erne om en mental sygdom hos kvinder, som indebærer et ubehag ved at spise og en afmagring som konsekvens deraf. Sygdommen er dog meget sjælden helt frem til slutningen af 1970'erne. Omkring år 1980 oplever psykiatriske hospitaler og praksisser imidlertid en voldsom stigning i antallet af patienter med anoreksi (Hammershøj 2005: 79; Brumberg 1988: 8-10). På dette tidspunkt går spiseforstyrrelser (anoreksi og bulimi) fra at være nogle af de mest sjældne til at være nogle af de mest almindelige psykiatriske lidelser (Hammershøj 2005: 80). Forekomsten af disse lidelser er i sagens natur svær at sætte præcise tal på, men der findes statistiske undersø- 
gelser, som tegner et billede af, at antallet af personer med anoreksi og bulimi i Danmark er steget fortsat op igennem 90'erne og 00'erne er (Due et al. 2014: 124).

Det er svært at forestille sig andet end, at denne udvikling er et udtryk for samfundsmæssige eller kulturelle forandringer. Selvom diagnosen anoreksi er en klassifikation af individer, synes det rimeligt at tale om en social psykopatologi, som er særegen for vestlig kultur (Wax og Cassel 1990: 135; Sundhedsstyrelsen 2005). Det er formentlig heller ikke tilfældigt, at denne udvikling i spiseforstyrrelser sker samtidig med fremkomsten af de samfundsmæssige vilkår, som sociologer kalder post- eller senmoderne. Hvorfor denne udvikling? Hvilke samfundsmæssige strukturelle forandringer kan tænkes at producere den symptomatiske adfærd, som vi kender fra anorektikere? I denne artikel er det min hensigt at læse anorektikeren (som persontype, som fænomen, som eksempel) gennem et samtidsdiagnostisk perspektiv, der har sit udgangspunkt i teoretisk psykoanalyse og det ovenfornævnte nydelsesimperativ.

Den samtidsdiagnostiske disciplin siges normalt at høre under sociologien. Siden Durkheim, Marx og Weber har vi set undersøgelser, hvor konkrete fænomener sættes i relation til samfundet som helhed, som dermed diagnosticeres. Nogle vil måske derfor være overraskede over se psykoanalysen anvendt med samme formål. Det er imidlertid ærindet i analysen nedenfor. Netop i den teoretiske psykoanalyse finder vi en grundlæggende spørgen til, på hvilken måden man som menneske er nødt til at relatere sig til det sociale felt. Det psykoanalytiske subjekt er ikke blot et produkt af historie og sprog, men heller ikke fuldstændig i kontrol med, hvad hun siger og gør. På den måde adskiller psykoanalysen sig fra den strukturalistiske sociologi på den ene side og fra ego-psykologien på den anden. Det menneskelige subjekt er fundamentalt splittet mellem det bevidste og det ubevidste, mellem seksualiteten og civilisationen, mellem jeg'et og den Anden. Psykoanalysens opgave er derfor ikke, som den undertiden fejlagtigt udlægges, at befri individets naturlige behov fra socialitetens undertrykkende virkning, således at individet bliver herre i eget hus. Tværtimod er formålet at vise, hvorledes følelsen af "ikke at passe ind" i kulturen er et normalt vilkår ved det at være menneske, som netop aldrig nogensinde er herre i eget hus. Sigmund Freuds banebrydende og potentielt frigørende indsigt var, at vi alle er patologiske; vi har alle vore mærkværdigheder, symptomer, uforståeligheder og urimeligheder - nogle mere omfangsrige end andre. I den henseende kan analyse per se sammenlignes med et spejl, der viser os og konfronterer os med vores patologier, og som gør det muligt at genkende, tage ansvar for og udfordre disse. 


\section{Analysestrategi: Om eksemplarisk metode}

Anoreksi er et komplekst fænomen, som kan tage sig ud på mange måder. Hvert enkelt tilfælde er på sin vis unikt. Mit formål er dog ikke at kortlægge alle nuancerne i de forskellige former for udtryk og årsager, anoreksi kan have. Mit forehavende er i stedet at forstå og fortolke anoreksi som en individuel reaktion på en samfundsmæssig udvikling. Anoreksi er ikke bare en diagnose af et individs psyke, men også et symptom på den kultur, som det anorektiske individ befinder sig midt i og reagerer på. I min analysestrategi er jeg inspireret af det, som kaldes "eksemplarisk metode" (Hansen og Ingemann 2016). Ligesom en kuglepen er et godt eksempel på et skriveredskab, er anoreksi et godt eksempel på en patologisk reaktion, der opstår i forsøget på at efterleve samtidens imperativ om at nyde. Ved at undersøge en kuglepen kan man blive klogere på, hvad et skriveredskab er, og på lignende måde kan man ved at undersøge anoreksi blive klogere på, hvad det vil sige at være et menneskeligt subjekt i et postmoderne samfund. Anoreksi er ganske vist ikke noget almindeligt, normalt eller gennemsnitligt eksempel. Formålet med analysen er da også at fremskrive det

"der går udover det almindelige, det normale, på en måde, så det siger noget om det almindelige selv, som vi måske ikke hidtil har været opmærksomme på. Eksemplet er den del af det normale, der på én gang er en form for undtagelse fra det og indbegrebet af det, fordi det sætter det normale i et nyt lys" (Bjerre 2015: 97).

Det er min påstand, at anoreksi udgør netop sådan et eksempel, der tvinger os til at tænke over samfundet på en ny måde. Målet med analysen nedenfor er ikke bare at bidrage til forståelsen, men at ændre forståelsen af, hvad der kendetegner vores samfund i dag.

Artiklen skrider frem gennem analyse af udvalgte udsagn fra anorektikere. Metoden kan her siges at være eksemplarisk i mere end én forstand. Ordet "eksempel" kommer af det latinske ord "eximere", der betyder at "tage ud"4. De udsagn som citeres nedenfor er netop udtagne blandt mange mulige, fordi de illustrerer en struktur særligt godt. Det eksemplariske kan imidlertid også forstås som noget, der på sin vis først bliver til, idet eksemplet sættes. Dick Fosbury er fx ikke bare et "godt eksempel" på en højdespringer. Med sin "ryggen først"-teknik ændrede han forståelsen af, hvordan det er muligt at springe højdespring. Vi kender denne betydning af det eksemplariske fra udtrykket at sætte et eksempel: "At sætte et eksempel er at gøre noget, der egentlig ikke var et eksempel til et eksempel på noget, vi 
endnu ikke kendte til, men som herefter kan ses i lyset af eksemplet" (Bjerre 2016: 31). Anorektikernes subjektive erfaringer er eksemplariske, fordi de i væsentlig forstand peger ud over sig selv. De er netop eksempler på noget og virker derfor som genstand for tænkning. Analysearbejdet nedenfor består således i at kredse om, sætte ord på og give betydning til, hvad det er, anoreksi er et eksempel (og et symptom) på.

De udsagn fra anorektikere, som optræder i denne artikel, har i de fleste tilfælde deres oprindelse som online forumindlæg. Gengivelsen af disse forumindlæg er anonymiserede af hensyn til forumbrugerne. Alle navne, som optræder i artiklen, er fiktive. Fordelen ved at granske en empiri af denne karakter er, at internetbrugerne på grund af formatet kan dele tanker og følelser, som de højst sandsynligt ikke udtrykker andetsteds (Bargh et al. 2002). I anoreksilitteraturen er man blevet opmærksom på eksistensens af det, man kalder "pro anorexia"-sider, dvs. online hjemmesider og fora hvor anoreksi aktivt promoveres. Værd at fremhæve her er Williams og Reids online interviewundersøgelse af anorektikere, som er rekrutteret gennem disse pro-anorektiske sider. Nedenfor henviser jeg flere gange til citater fra anorektikere, som er bragt i Williams og Reids artikel "Understanding the experience of ambivalence in anorexia nervosa: the maintainer's perspective" (2010).

Derudover henviser jeg til udvalgte forumindlæg fra girlstalk.dk, iform.dk og "proED"s. Sidstnævnte er en underkategori til forumsiden reddit.com og et eksempel på et populært pro-anorektisk forum, som har adskillige indlæg hver dag. "proED" står for "pro eating disorder". Her deler forumbrugerne tips, følelser og oplevelser med deres sygdom. For eksempel tips til hvordan man taber sig, hvordan man skjuler sin sygdom for sine forældre, hvordan man skal håndtere følelser af sult og lignende. På pro-anorektiske sider som denne, kan brugerne give udtryk for synspunkter, som i offline sammenhænge ikke ville være velansete (Adams et al. 2005: 1295). Pro-anorektiske internetfora opfattes derfor ofte af brugerne som det eneste sted, hvor de kan opnå støtte til, accept af og forståelse for deres situation (Williams og Reid 2010: 552).

Artiklen består i det følgende af to dele. Jeg analyserer i disse dele to forskellige måder, hvorpå nydelse kan være struktureret. For det første som fantasien om den behagelige mer-nydelse, der gemmer sig på den anden side af et vægttab. For det andet som den ubehagelige mer-nydelse, der eksisterer i visheden om at være afhængig af en sygdom, der er så sundhedsskadelig, at man kan dø af den. I analysen er det formålet at vise, hvordan anorektikeren er et produkt af over-jeg'ets umulige krav om skabe den perfekte krop, som hun kan nyde og være stolt af. I 
forsøget på at leve op til dette påbud bliver anorektikeren tyndere og tyndere, men det er alligevel, som om fantasien om den perfekte krop forsvinder længere

og længere væk. Til sidst er der derfor ikke andet tilbage for anorektikeren end at nyde sine egne symptomer, dvs. de regler, hun har sat op for sig selv for at bidrage til sit vægttab. Artiklen er altså opbygget på den måde, at dets to dele repræsenterer en overgang fra den behagelige nydelse af fantasien om den perfekte krop til den ubehagelige nydelse af en faretruende sygdom. Hen imod slutningen af kapitlet bliver de anorektiske fantasikonstruktioner, som analyseres, gradvist mere og mere patologiske. Vi starter imidlertid med en kort beskrivelse af, hvilken rolle refleksivitet spiller i et moderne samfund.

\section{Den fantasmatiske forestilling om at tabe fem pund}

Ifølge sociologen Anthony Giddens er det moderne samfund kendetegnet ved en gennemgribende refleksivitet. Refleksivitet henviser ifølge ham til tilbøjeligheden "til konstant revision på baggrund af ny information eller viden" (Giddens 1996: 32). I nutidens samfund er intet givet på forhånd; der er ingen dogmer, man kan sætte sin lid til, og ingen traditioner der kan udgøre det faste fundament, som livet bygges på. Selv de mest intime præferencer ( $\mathrm{fx}$ hvad og hvordan man ønsker at spise), opfattes i stigende grad, som noget der skal vælges refleksivt (Giddens 1996: 46).

Ikke kun den individuelle intimsfære, men også moderne autoriteter angribes af refleksivitet, og det er derfor aldrig givet eller på nogen måde selvindlysende, hvilke af disse autoriteter man som individ skal lytte til. "Der er", for at citere en anden kendt sociolog, Zygmunt Bauman, "ganske enkelt for mange af dem, og de kolliderer med hinanden og modsiger hinandens bud" (Bauman 2006: 15). Selvom vi sjældent er i stand til at se det direkte, kan man derfor sige, at den store Anden er splittet, mangelfuld og inkonsistent. Den store Anden er det lacanianske begreb for den symbolske orden, der medierer forholdet til andre menneskelige subjekter (Evans 1996: 136). Den Anden henviser til andre mennesker per se, dvs. ikke bare konkrete mennesker, men også den abstrakte forestilling herom. Den Anden er altid til stede - eksempelvis som et slags guddommeligt blik, der hviler på os, når vi sidder og foretager os noget så uskyldigt som at spise. Det er derfor, man kan nyde eller skamme sig over, hvad man spiser, selvom man er alene.

Karakteristisk for anorektikeren er hendes ønske om at leve op til omverdenens (den Andens) forventninger (Sundhedsstyrelsen 2000). Hun begærer (at være ob- 
jekt for) den Andens begær, at blive elsket, at blive anerkendt, og hun er derfor ekstremt opmærksom på den Andens blik på egen krop. Et eksempel på det ser vi af følgende citat: "Nogle gange tog jeg dem [drengene] i at glo på mig og hviske sammen. Hvad sagde de mon? Jeg følte mig så grim" (Scrivener 2014: 45-46). Det, som anorektikerens subjektive erfaringsverden kan tydeliggøre for os, er, at moderniteten ikke blot, som Giddens formulerer det, "rummer mulighed for en intimitet og selvudfoldelse, som er fraværende i mange mere traditionelle sammenhænge" (Giddens 1996: 24), men at modernitetens muligheder også kommer sammen med nye former for patologier, som opstår på grund af usikkerheden ved en manglende tradition at læne sig op ad. Konsekvensen af den refleksivitet, som kendetegner det moderne, er, at det sjældent er særligt klart, hvad den Anden kræver af os, hvilket kan resultere i tvivl ("Hvad sagde de mon?") og en følelse af skam ("Jeg følte mig så grim").

I en psykoanalytisk optik er over-jeg'et den kontrolinstans, der gør en person i stand til at leve op til den Andens forventninger. Som barn er det eksempelvis mine forældre, der agerer den store Anden, og som kræver, at jeg opfører mig på bestemte måder i bestemte sammenhænge. Over-jeg'et er imidlertid den instans, der gør mig i stand til at leve op til disse krav, selv når forældrene ikke er i nærheden. Anorektikeren er et paradigmatisk eksempel på, hvordan over-jeg'ets struktur fungerer, fordi hun på en ekstrem og derfor ekstremt tydelig måde forsøger at adlyde over-jeg'ets krav

- dvs. først og fremmest kravet om at have en slankere krop. Ifølge Žižek er over-jeg'et en glubsk instans, som altid kræver mere af sit subjekt. Man kan ganske enkelt aldrig leve op til over-jeg'ets påbud på en passende måde. Uanset hvad man gør, er det altid enten for meget og/eller for lidt (Žižek 2008: 407). Et godt eksempel på det, ser vi af følgende citat, fra det danske "iForm"-forum:

"Der er os dage hvor jeg har spist rigtig lidt. Og hvor jeg dagen efter finder ud af jeg har tabt mig. Så blir jeg først rigtig glad. Men så fortryder jeg alligevel og spiser morgenmad. Exvis 2 franskbrøder $m$ smør og ost. Får derefter så dårlig samvittighed. At jeg motionere + render mindst 20 gange op og ned a vores trappe"

Uanset hvad hun gør, er det aldrig godt nok. Hvis hun taber sig, får hun dårlig samvittighed og giver sig til at spise. Men dét får hun også dårlig samvittighed over, hvilket resulterer i, at hun tvangsmæssigt motionerer på stedet. Over-jeg'et er aldrig tilfreds, men kræver altid noget mere og noget andet end det, hun gør. Selvom hun (for en stund) kan glæde sig over at tabe sig, er hun aldrig i stand til 
at nyde sit eget (slanke) selvbillede. Anorektikeren er optaget af sit spejlbillede, men modsat narcissisten kan hun ikke lide, hvad hun ser. Derfor retter hun et hysterisk begær mod sin egen mangelfuldhed. Uanset hvor tynd hun måtte være, er hun altid utilfreds og vil være endnu tyndere. Det, som kendetegner det hysteriske subjekt ifølge den lacanianske psykoanalyse, er imidlertid, at hun opnår en form for tilfredsstillelse i selve utilfredsheden (Fink 1999: 121-125). Den anorektiske fantasi tilbyder altså sit subjekt nydelse, ikke fordi begæret tilfredsstilles, men tværtimod fordi begæret holdes i live ved aldrig at kunne blive stillet tilfreds. En forumtråd oprettet af Tanita med overskriften: "The difference of five pounds" kan fint illustrere dette:

"I'm currently sitting at 122-123 pounds [55kg, red.] (though I haven't stepped on my scale for a while because I hate seeing that number), but about a month ago, I was at 117. I still was at a healthy BMI, but oh man, did my life feel great back then. I remember feeling confident no matter what I wore, even wanting the weather to get warmer so I could flaunt my legs and arms. I ate without shame of looking like a pig, but with the self-assurance that I looked fit and healthy. Now? I feel disgusted when I wear skinny jeans and tight shirts. I want to eat all of my meals alone and in a corner. I know it's just five, FIVE, pounds, but the difference it makes in my head is ridiculous. I am not the same person I was when my weight was in the teens [<120 pund, red.]. 117 wasn't even my GW [ground weight, red.]. I can't believe I let myself back up to 122" (Tanita)

En række af andre forumbrugere stemmer i og skriver, at de har det på præcis samme måde - fx: "Exact same thing happened to me. Was 108 then 113 and I feel like I've backslid into oblivion" (Rachel). Brugerne holder sig selv ansvarlige for deres egen utilstrækkelighed og manglende evne til at få fat i nydelse, hvilket resulterer i skyldfølelse og selvhad: "This is the exact thing I'm going through right now. Went from 116-118 to 124 and I can feel the weight on my thighs and stomach, and I hate myself for it" (Tracy).

Den væsentlige pointe er, at anorektikerens indstilling netop er kendetegnet ved, at hun altid lige mangler at tabe fem pund før alt er godt og skønt. Fantasien om det perfekte forhold til sin krop, hvor man ikke skammer sig, men derimod stolt bærer den og viser den frem, er altid fem pund væk - uanset hvor tynd man ellers måtte være. Netop derfor kan anorektikeren blive ved med at opretholde og være i den fantasmatiske forestilling om en nydende tilværelse på trods af begærets ikke-tilfredsstillelse. Det, som anorektikeren oplever som en barriere, der står i 
vejen for nydelsen (de fem pund i kropsvægt som er for meget), er i virkeligheden præcis det, som opretholder illusionen om den komplette nydelse. Ifølge Žižek er fantasi netop et begreb for det, som genererer subjektets begær og giver det en retning, samtidig med at den skærmer for den sandhed, at dette begær er grundet i en konstitutiv mangel og derfor aldrig kan stilles tilfreds (Žižek 1997: 7).

I denne forumtråd skaber forumbrugerne retroaktivt en fantasi om dengang, hvor de vejede fem pund mindre og derfor levede en tilværelse uden skam og fyldt med selvtillid. Et par af forumbrugerenes svar i tråden synes da også at være tæt på at erkende, at der er tale om en imaginær fantasikonstruktion: "This is me too. I was at 116-117 for a few months and now I'm seeing 124. 121 even kills me. I thought I was imagining things when I feel bigger" (Katie) eller "This is me except with 2 pounds. Apparently my life will be magical and perfect and nothing will ever go wrong again at 108" (Barbara).

Skulle disse anorektikere rent faktisk tabe den ønskede kropsvægt, ville det næppe medføre den lykkelige tilværelse, som de beskriver. Tag eksempelvis denne person, som i en anden forumtråd skriver følgende:

"I was at around $142 \mathrm{lbs}$ in january and now im down to about 124, but $i$ dont feel like i've lost any weight. All my clothes seem to fit about the same and i feel like my face and body look exactly the same. I feel like i'm going crazy, i've lost nearly 20 pounds according to my scale but literally NOTHING has changed and I'm losing the little motivation i had. I just feel so lost" (Ida)

Her har vi et eksempel på, hvordan den traumatiske sandhed om fantasien træder frem for anorektikeren på en lidt for tydelig måde. Selvom hun har tabt sig næsten 20 pund, oplever hun ingen forandring ("NOTHING has changed"). Når man overskrider barrieren og opnår det vægttab, som man i første omgang ønskede, finder man, at der på den anden side er: Intet. Det, som denne forumbruger giver udtryk for, er altså den melankolske oplevelse af at tabe selve begæret. Uden begærets vitalitet har livet ingen retning, og alt føles meningsløst og ligegyldigt.

Konsekvensen af anorektikerens hysteriske begær er, at hun så at sige "skræller" mere og mere af sig selv for at finde ind til et umuligt begærsobjekt. Paradoksalt nok opnår hun imidlertid det modsatte: Det, som hun finder, er ren og skær krop frarøvet sin fantasmatiske status som ophøjet objekt. Hvad anorektikeren ikke ved er, at det er selve barrieren for eller umuligheden af perfektion, som opretholder forestilling om perfektion. Fjernes barrieren, fjernes også meningen med projektet, motivationen og nydelsen: "I just feel so lost". 
Anorektikeren begærer som nævnt (at være objekt for) den Andens begær. Problemet i dag er, at den Andens begær er usammenhængende og inkonsistent (Salecl 2012: 63-65). Det anorektiske subjekts erfaringsverden kan ses som en direkte konsekvens heraf. Forventningen til det postmoderne individ i en vestlig kultur i dag synes at være, at hun skal nyde, samtidig med at hun skal give afkald på at nyde. Af en ung kvinde forventes det eksempelvis, at hun skal kunne slappe af, slippe sig selv løs og eksempelvis nyde god mad og våde byture. Men det forventes samtidig også, at hun tager kontrollen over sin egen krop og ikke giver efter for umiddelbare lyster til eksempelvis store mængder af mad, alkohol og sex. Det er muligvis dette umulige fantasmatiske begærsobjekt, som Tanita beskriver retrospektivt ovenfor: "I ate without shame of looking like a pig, but with the self-assurance that I looked fit and healthy". Det er som om, at det, som den store Anden kræver af os i dag, er: at man skal spise som en gris, men uden skamfølelsen af at ligne en gris; at man skal spise usunde sager, men samtidig se sund ud; at man skal spise på en afslappet måde, men samtidig have stram kontrol over sin krop.

Citatet af Tanita ovenfor viser, hvordan anorektikeren kan leve i en fantasmatisk afstandsrelation til sit begærsobjekt, dvs. den behagelige forestilling om at være en kvinde, som er stolt af sin krop, og som nyder at spise, nyder at se sig selv i spejlet osv. At anorektikeren aldrig får fingrene i dette begærsobjekt, indebærer som bekendt også en væren med stor fortvivlelse, smerte og ubehag. Det har da også fået nogle, eksempelvis psykiateren Sollberger, til at foreslå, at anoreksi er en identitetskonstruktion baseret på en afvisning af det postmoderne nydelsesimperativ. Modsat de mange former for postmoderne identifikation, som handler om at behage sig selv, er anorektikerens identitet ifølge ham konstrueret som et "autonomt ubehag" (Sollberger 2014: 246).

Jeg mener, at Sollberger har ret i det sidste, men tager fejl med det første. Anorektikeren afviser ikke nydelsesimperativet, hun er derimod dybt optaget af at blive begæret, elsket og anerkendt af den Anden. Anoreksi er derfor en gentagelse af forsøget på at leve op til nydelsesimperativet, som mislykkes i en sådan grad, at det bliver decideret patologisk og selvdestruktivt. Anorektikeren vil så gerne elske og nyde sit forhold til sin krop, og netop derfor mislykkes hun.

Sollberger har ikke desto mindre ret $\mathrm{i}$, at anorektikeren finder sin væren i et "autonomt ubehag" - ikke fordi hun afviser den Anden, men tværtimod fordi hun lever op til den Andens forventning om, at kvinder skal have kontrol over sin krop og være tynde, i en sådan grad, at det bliver for meget og derfor ubehageligt. I en vis forstand er anoreksi derfor ikke bare en irrationel, men nærmest hyperrationel, reaktion på samtidens krav: 
"Pointen er, at når jeg ikke kan kontrollere min tilværelse, er jeg patologisk knusdygtig til at følge de regler, som andre ville ønske, at de kunne følge. Det er ikke engang svært for mig. Simpelt, rationelt og elegant overholder og udfører jeg opskrifter, vejledninger og regler med nærmest algoritmisk perfektion, indtil der ikke er andet tilbage af mig end selve den udførelse. Her kan jeg være. Her kan jeg overleve. Her har jeg en stemme, en magt og en ret. Som omvandrende krop for korrekt livsstil, spisning, træning" (Muldtofte 2016)

Anoreksien tilbyder sit subjekt en følelse af at være i kontrol. Anorektikeren undertrykker sine følelser (sult, svimmelhed og anden ubehag) og tager kontrollen over sin krop. Ligesom den religiøse asket kan anorektikeren derfor finde en nydelse i sin lidelse. Hun giver afkald på nydelse og får derved adgang til (mer-)nydelse. Men i modsætning til den troende asket, hviler hun ikke i visheden om, at hun gør det rigtige. Tværtimod tumler hun rundt i tvivlen og finder sin eksistens ("Her kan jeg være") i den ringe trøst, det er at leve op til regler og vejledning, som er baseret på moderne viden. Hun er et produkt af postmoderne refleksivitet. I forhold til det traditionelle samfund er der på den måde sket en form for refleksiv omvending: I dag ønsker vi ikke frigørelse fra traditionernes undertrykkende regulering af begæret. Vi ønsker os tværtimod regulering af begæret, dvs. opskrifter, vejledninger og regler, som vi kan følge.

I den flydende modernitets åbne miljø findes der en tryghed i strenge og stramt kontrollerede opskrifter, vejledninger og regler. For anorektikeren bliver selvreguleringen imidlertid ekstrem. Følelsen af at være i kontrol erstattes hurtigt med en følelse af, at anoreksien har taget kontrollen over hende (Williams og Reid 2010: 564). Den behagelige glæde ved at tabe sig erstattes af en ubehagelig tvang til selvsamme. Anoreksien konsumerer nærmest i bogstavelig forstand den person, som har den. I ekstreme tilfælde minder anorektikerens forhold til sin sygdom derfor om en misbrugers forhold til euforiserende stoffer. Det er temaet i den næste og sidste del af artiklen, hvor jeg vil komme ind på, hvordan anoreksien fremtræder som en slags "forbudt nydelse". Sygdommen er både sundhedsskadelig og farlig, men derfor også et spændende "drug". 


\section{"I dont want to die, but I dont want to recover"}

Det, som Sollberger overser, er, at der kan være en slags behag i selve ubehaget. Det er den nydelse, som eksisterer hinsides lystprincippet, dvs. hinsides lysten til at leve eller spise eksempelvis. Den eksisterer på grund af en viden om, at man befinder sig på forbudt område: Det er farligt og ubehageligt og giver derfor anledning til en spændende mer-nydelse (Žižek 2008: 239). Det, som kendetegner anoreksi i ekstreme tilfælde, er netop, at anorektikeren opfylder sine egne indre forpligtigelser til at spise mindre og motionere mere på trods af den eksterne trussel, som døden udgør. Ligesom en soldat i krig, der følger ordrer fra sin overordnede uafhængigt af risikoen for at dø, følger anorektikeren de principper, som hun har stillet op for sig selv, uanset at hun risikerer at dø af det. Og ligesom den udsendte soldat kan blive afhængig af spændingen, kan anorektikeren også blive afhængig af en form for rus.

Der er ikke nogen tvivl om, at anoreksi indebærer store sundhedsmæssige risici. I en efterundersøgelse af anorektikere fandt man, at dødeligheden efter 20-30 år var 15-18 \% hovedsageligt på grund af underernæring eller selvmord (Sundhedsstyrelsen 2005: 17). Ifølge Sundhedsstyrelsen er det et centralt problem for anorektikere, at de benægter sygdommens alvor og dens sundhedsmæssige risici (Sundhedsstyrelsen 2005: 15-16). Datamaterialet fra Williams og Reids undersøgelse tegner imidlertid et andet billede. Når interviewpersonerne (pro-anorektiske forumbrugere) beskriver deres sygdom, nævner de ofte, at den er sygelig, og at de kan dø af den. Her er nogle få (blandt flere mulige) eksempler (Williams og Reid 2010: 561): "It's a disease no different from cancer, or multiple personality disorder" (Grace) og "Anorexia is a potentially fatal disease. It's like cancer. You don't treat it you're gonna die of it" (Anita)

En tredje anorektiker (Maria) understreger også, at anoreksi er en sygdom, man kan dø af. "I dont want to die, but I dont want to recover", skriver hun (Williams og Reid 2010: 562). Det er ikke særegent for Maria, men derimod en udbredt tendens blandt anorektikere, at de ikke ønsker at blive raske eller at skille sig af med sin spiseforstyrrelse. Når så mange anorektikere holder fast i deres lidelse velvidende, at de risikerer at miste livet, så er det, vil jeg mene, et klart tegn på, at der er en form for nydelse forbundet med denne lidelse. Denne nydelse eksisterer som nævnt hinsides lysten til at spise eller leve. I ekstreme tilfælde resulterer sygdommen derfor i døden. I mindre ekstreme tilfælde er det netop lysten til at leve og til at blive rask, der er skyld i, at det ikke ender så galt. I sådanne tilfælde lever anorektikerne imidlertid med en enorm ambivalens. På den ene side ønsker de at 
være fri for sygdommen, men på den anden side opleves sygdommen som "den eneste måde, hvorpå følelsen af lykke kan opnås" (Williams og Reid 2010: 551; egen oversættelse).

Anorektikere er således ofte ambivalente i forhold til at indgå i et helbredelsesforløb og er forbeholdende over for at skille sig af med sygdommen (se fx Colton \& Pistrang 2004; Reid et al. 2008; Serpell et al. 1999), hvilket skaber stor forundring for dem, som følger med i et anorektisk sygdomsforløb fra siden. Anorektikeren kan imidlertid ikke se sin patologi fra siden, fordi hun befinder sig midt i den. Når anorektikeren møder uforstående reaktioner fra omverdenen, er der derfor en risiko for, at hun isolerer sig, så hun bliver alene med sig selv og sin sygdom. Relationen til sygdommen kan i den situation blive en slags erstatningsrelation, som gør, at hun slipper for at forholde sig til andre mennesker. Nogle gange sker det derfor også, at sygdommen personificeres som en ven eller en stemme:

"My anorexia plays the role of my best friend. It is always there for me. It makes me happy and always tells me the truth... that I am fat, and underserving and that food is not what's going to make me happy. It teaches me what I need to know... how to lose weight, how to lie to people, how to avoid feeling by not eating. It holds my hand when I need to feel safe. It sleeps next to me every night. It makes me feel safe and secure" (Grace i Williams og Reid 2010: 560)

Anoreksien bliver i dette tilfælde en personificering af, hvad Grace føler. "Den" fortæller hende "sandheden" om, hvad hun er for den Anden ("fat and undeserving"), dvs. sandheden, sådan som hun oplever det. "Den" skaber meningsfuldhed midt i det virvar af meningsløse følelser og får hende til at føle sig "tryg og sikker", fordi den dækker over den store Andens ovenfornævnte inkonsistens. Man kan måske sige, at anoreksien er den konstruktion, som er nødvendig for, at anorektikeren kan give mening til sine følelser. Hvis det er rigtigt, er den anorektiske tilstand ikke bare en tilfældig patologi, men derimod den konstruktion som er nødvendig for at dække over den Andens mangel.

Den sidste anorektiker, som jeg vil citere, har skrevet et længere indlæg om, hvordan hun på trods af forsøget på at slippe af med sygdommen oplever, at den vender tilbage til hende som en stemme. Her er to udpluk, som viser, hvordan denne stemme indbyder til den forbudte nydelse det er at sulte sig selv:

"[jeg] føler stadigvæk, at min anoreksi lever i mig. Jeg føler nogen gange, at jeg høre 'hende' tale til mig, prøver at få mig til at sulte mig igen. Jeg høre den 
stemme tit og tager mig selv $i$ at trenke, at jeg er en fed ko som ikke fortjener at spise og nogen gange sulter jeg mig i flere dage, indtil hun er væk igen.. Indtil jeg kommer til fornuft" (Kristina)

og

"Jeg vil så gerne være glad for mig selv nu.. Og det skræmmer mig sådan, at jeg høre hende hele tiden.. At hun er der endnu og ikke er givet op på mig.. Samtidig, foler jeg, at mit liv ville være tomt uden den stemme til at styre hoad jeg spiser" (Kristina)

Den stemme, som beskrives her, tilhører over-jeg'et. Over-jeg'et kan, som vi allerede har set, efterlade subjektet med en intens følelse af utilstrækkelighed ("jeg er en fed ko som ikke fortjener at spise"). Det interessante er imidlertid erkendelsen af at være afhængig af en stemme, som har netop denne virkning på en. Afhængigheden eksisterer, fordi det er muligt at nyde det symptom, som man selv producerer. Af de to citater kan vi se, hvordan anoreksien fremtræder som en slags "forbudt nydelse", som modstilles fornuften ("Indtil jeg kommer til fornuft"): En stemme, der hvisker dig i øret og beder dig give efter, give slip og lade anoreksien tage kontrollen ("styre hvad jeg spiser"). Når det forbudte på denne måde er at sulte sig, mens det fornuftige er at spise, har vi en dialektisk omvending af det tidligere normale forhold mellem forbud og nydelse.

I et traditionelt forbudssamfund blev det normalvis anset som fornuftigt at spise få kalorier, motionere hyppigt og så videre. Nydelsen er da tilgængelig som en overskridelse af det fornuftige: fx ved at spise noget lækkert og gerne usundt. Men $i$ et samfund, hvor nydelse er normen, ja endda et imperativ ("Jeg vil så gerne være glad for mig selv"), er overskridelsen omvendt mulig ved at lytte til den anorektiske stemme, som siger, at man skal sulte sig selv.

At nyde sig selv er ikke længere nogen privat hemmelighed, men derimod en offentlig pligt. Anoreksi derimod er et tabu, en hemmelighed, som man prøver at skjule for forældre, venner og lærere. Det virker fx ikke usandsynligt, at en kvinde i den tidlige modernitet (starten af det 20. århundrede) kunne finde på at skjule eller lyve om, at hun havde nydt et stort stykke chokoladekage, hvorimod en kvinde i vores tid nærmest stolt kunne fortælle det til veninderne eller vise det frem ved at dele et billede af det på et af de sociale medier. I lyset heraf kan anoreksien måske forstås som den nye, hemmelige og forbudte nydelse, som er mulig i kraft af disse strukturelle forandringer. 
Som eksempel står anoreksi altså frem som et symptom på vores kulturelle forhold til nydelse. Det er svært at forestille sig, at betingelserne for anoreksi skulle være til stede i en kultur, som ikke er så optaget af nydelsen, som vores er det. Fremkomsten af anoreksi sker på grund af en overopmærksomhed på nydelsen. Anorektikeren er et eksempel på en person, der er så ekstremt optaget af at efterleve påbuddet om, at man skal nyde sig selv og sin krop, at det slår over i sin modsætning og bliver en smertefuld og ubehagelig lidelse, fordi hun altid føler sig skyldig over ikke at nyde nok og ikke at nyde godt nok. Anoreksi er med andre ord et paradigmatisk eksempel på en patologisk reaktion på det nydelsesimperativ, som kendetegner vores samtid.

Anoreksien er også et radikalt eksempel på, hvordan over-jeg'et terroriserer sit subjekt. Det virker utænkeligt, at en anorektiker nogensinde skulle kunne være i stand til at stoppe op og sige: "Jeg er nu fuldt ud tilfreds med min krop. Jeg behøver ikke længere at tabe mig". Det gælder imidlertid ikke kun anorektikeren, men også nærmest alle andre, vil jeg hævde. Det er immervæk de færreste af os (hvis nogen overhovedet), der har et fuldstændig uproblematisk forhold til sin krop. Løsningen på dette samfundsproblem i tiden er selvfølgelig ikke at lytte til fitnessindustriens råd om at lave om på sin krop. "Gør noget godt for dig selv", som det hedder i sloganet fra Fitness World. Men løsningen er heller ikke den, som den positive psykologi ynder at fortælle os: at "du skal lære at elske dig selv". Som vi har set, er det forsøget på at leve op til påbud som disse, der resulterer i et patologiske tanke- og adfærdsmønstre á la anorektikerens. Det, som vi bør fortælle hinanden, er måske i stedet: "Det er okay, at du ikke nyder; at du ikke elsker dig selv; at du ikke elsker din krop". Først når vi indser, at misforholdet til kroppen er et strukturelt vilkår ved det at være menneske, kan vi begynde at acceptere det og på den vis få et mindre patologisk forhold til kroppen. Nydelse (fx idéen om at have en flot, slank krop, som man er stolt af) har det med at fremstå som noget, der venter på os lige rundt om hjørnet (hvis vi fx træner lidt hårdere eller spiser lidt mindre). Når vi deltager i jagten på nydelsen, stiller vi derfor os selv i en umulig position.

Formålet med analysen ovenfor har derfor ikke været at angive (endnu) en manual, som kan fortælle os lige præcis, hvad man skal gøre for at lære at elske sig selv og sin krop, men derimod at vise, at dette projekt er dømt til at mislykkes. Det menneskelige subjekt er altid splittet og adskilt fra den fuldendte nydelse. Kun ved at acceptere og antage splittelsen er det muligt at indtage en ny og bedre position i forhold til den store Anden, som våger over os, når vi spiser. 


\section{Noter}

${ }^{1}$ https://www.dr.dk/tv/se/petra-elsker-sig-selv/-/petra-elsker-sig-selv-1-6

${ }^{2}$ For en mere udførlig beskrivelse af denne samtidsdiagnose se McGowan 2004

3 Se eventuelt Ugilt 2015: 13-16 for en illustration af forskellen mellem "lyst" og "mer-nydelse"

4 http://denstoredanske.dk/Sprog,_religion_og_filosofi/Sprog/Fremmedord/e-ek/ eksempel

${ }^{5}$ https://www.reddit.com/r/proED/

\section{Referencer}

Adams, J., K. Rodham og J. Garvin (2005). »Investigating the 'self' in deliberate self-harm «" side 1293-1309 i Qualitative Health Research, 15(10)

Bargh, J.A., K.Y.A. McKenna og G.M. Fitzsimmons (2002). »Can you see the real me? Activation and expression of the 'true self' on the internet«, side 33-48 i Journal of Social Issues, $58(1)$

Bauman, Zygmunt (2006). Flydende modernitet. Hans Reitzels Forlag

Bjerre, Henrik Jøker (2015). Analysér!. Forlaget Mindspace

Bjerre, Henrik Jøker (2016). »At sætte et eksempel«, side 27-48 i Brian Benjamin Hansen og Jan Holm Ingemann (red.): At se verden i et sandkort - om eksemplarisk metode. Samfundslitteratur

Brumberg, Joan Jacobs (1988). Fasting Girls: The Emergence of Anorexia Nervosa as a Modern Disease. London: Harvard University Press

Colton, A. \& N. Pistrang (2004). »Adolescents' experiences of inpatient treatment for anorexia nervose« side 307-316 i European Eating Disorders Review, 12

Dandanell, Tone Frank (2017). »Den nye feminismes nydelsessyge«, Slagmark: http://www. slagmark.dk/den-nye-feminismes-nydelsessyge

Dolar, Mladen (1998). »Introduction: The Subject Supposed to Enjoy«, side ix-xxvii i The Sultan's Court - European Fantasies of the East. London: Verso

Due, Pernille et al. (2014). Børn og unges mentale helbred. Forekomst af psykiske symptomer og lidelser og mulige forebyggelsesindsatser. København: Vidensråd for forebyggelse. 2014:1184

Evans, Dylan (1996). An Introductory Dictionary of Lacanian Psychoanalysis. London: Taylor \& Francis e-Library 2006

Fink, Bruce (1999). A Clinical Introduction to Lacanian Psychoanalysis: Theory and Technique. London: Harvard University Press

Giddens, Anthony (1996). Modernitet og selvidentitet. København: Hans Reitzels Forlag

Hammershøj, Lars Geer (2005). »Anoreksi som afsindigt selvdannelsesprojekt - diagnose af en social epidemi«, side 79-107 i Rasmus Willig og Marie Østergaard (red.): Sociale patologier. København: Hans Reitzels Forlag 
Hansen, Brian Benjamin og Jan Holm Ingemann (2016). At se verden i et sandkort - om eksemplarisk metode. Samfundslitteratur

McGowan, Todd (2004). The End of Dissatisfaction - Jacques Lacan and the Emerging Society of Enjoyment. State University of New York Press

Muldtofte, Lea (2016). »Jeg er omvandrende ekstrem korrekthed« i Information 2. december 2016

Reid, M., J. Burr, S. Williams og R. Hammersley (2008). »Eating disorders patients' views on their disorders and on an outpatients service: A qualitative study«, side 956-960 i Journal of Health Psychology, 13(7)

Salecl, Renata (2012). Valgets tyranni. Forlaget Philosophia

Scrivener, Emma (2014). Min vej ud af anoreksi. Forlagsgruppen Lohse

Serpell, L., J. Treasure, J. Teasdale og V. Sullivan (1999). »Anorexia nervosa: Friend or foe?« side 177-186 i International Journal of Eating Disorders, 25

Sollberger, Daniel (2014). »The Inversion of the Fall: On Identity Construction in Anorexia Nervosa«, side 244-251 i Psychopathology 2014;47

Sundhedsstyrelsen (2000). »Fakta om spiseforstyrrelser« http://www.sst.dk/ /media/D6B5896CF98C49AF9B030F31AAE6246A.ashx

Sundhedsstyrelsen (2005). Spiseforstyrrelser: Anbefalinger for organisation og behandling. https://www.sst.dk/ /media/A297287DE0F548A88DC8F8C44441A8A9.ashx

Wax, Murray L. og Joan Cassel (1990). »The looking glass self: Introductory notes on anorexia nervosa«, side 135-143 i Mid-American Review of Sociologi, Vol. XIV, No. 1-2

Williams, Sarah og Marie Reid (2010). »Understanding the experience of ambivalence in anorexia nervosa: the maintainer's perspective«, side 551-567 i Psychology \& Health, 25:5 https://doi.org/10.1080/08870440802617629

Žižek, Slavoj (1997). The Plague of Fantasies. London: Verso

Žižek, Slavoj (2008). The Ticklish Subject: The Absent Centre of Political Ontology. London: Verso

Žižek, Slavoj (2010). Ideologiens sublime objekt. København: Hans Reitzels Forlag

Žižek, Slavoj (2011). Living in the End Times. London: Verso 